\title{
Characterization of syngas produced from biomass gasification
}

\author{
Jan Najser ${ }^{1, *}$, Ondřej Němček ${ }^{1}$, and Marcel Mikeska ${ }^{1}$ \\ ${ }^{1}$ ENET Centre, VŠB -Technical University of Ostrava, 17. listopadu 15, Ostrava-Poruba CZ-708 33, \\ Czech Republic
}

\begin{abstract}
This conference paper presents biomass (wood chips from the production process of sawmills) as a renewable energy source to produce electric energy by gasification. Executed measurements from the gasifier with a fixed bed and properties of produced syngas are described in this paper. The goal is to use the produced syngas at co-generation units with piston combustion engines to produce electric energy and heat. The syngas composition is the final result of these measurements. The syngas from gasification contains pollutants which cause technical difficulties during its use in engines with internal combustion and for this reason it is necessary to choose an adequate system of syngas cleaning.
\end{abstract}

\section{Introduction}

World energy consumption trend is rising and surely it will not be limited by more efficient activities and technologies. The reason for this state of affairs is population growth but also the needs of industry and households. This is another reason of huge interests of new and cheaper sources of energy, alternative fuels, energy recovery and finally renewable energy sources which include biomass [1-3].

Current efforts to reduce $\mathrm{CO}_{2}$ emissions and the amounts used of fossil fuels are the cause of wider use of renewable fuels as well as waste [4]. This leads to the arising of new installation using local fuel sources as well as with various types of process waste [5]. Wastes are increasingly being used to produce electricity and heat. A high level of pollution in waste requires applying more efficient and resistant to different substances devices.

The current situation in the energy industry emphasize the desirability of implementation the small cogeneration systems to national grid. The interests in renewable energy sources as well as the use of waste generated in various processes are increasing [6]. The cogeneration units must meet the both criteria - economic ones as well as demand for high reliability and low environmental impact.

\footnotetext{
*Corresponding author: jan.najser@,vsb.cz
} 


\section{Experimental}

During gasification, generator gas is produced in the presence of a gasification medium within adequately selected conditions. The low heating value of the generator gas is usually about 4-7 MJ. $\mathrm{m}_{\mathrm{n}}^{-3}$, during gasification with oxygen is possible to obtain syngas with LHV from 14 to $18 \mathrm{MJ} . \mathrm{m}_{\mathrm{n}}^{-3}$. The produced gas contains primarily $\mathrm{CO}, \mathrm{CO}_{2}, \mathrm{H}_{2}, \mathrm{CH}_{4}$ and $\mathrm{N}_{2}$ if air is used as a gasification medium [7]. Besides these, the gas also contains other components, mainly undesirables such as dust, tars, alkali, sulphur and nitrogen compounds, hydrogen chloride, hydrofluoride etc [8]. The greater content of volatile inflammable matter gives rise to the greater amount of hydrocarbons in a form of permanent gases such as ethylene, acetylene, benzene, toluene and xylene. As well, high water content results in a formation of tars [9].

In terms of combustion in engines or turbines, ethylene, benzene and toluene are desirable substances - they increase the total low heating value of syngas and improve its combustion properties. However, these substances are undesirable for fuel cells.

Before the syngas can be used in combustion engines or turbines, it needs to be cleaned [10]. Requirements for the cleanliness of produced syngas rise in the case of combustion engines and turbines to extremely low values that are required for trouble-free operation of fuel cells.

By comparing these requirements with a composition of common syngas from the biomass gasification, it can be concluded that without the effective cleaning it is not possible achieve the required syngas quality [11]. To be able to use the syngas in a combustion engine, dust and tar contents must be monitored. The amount of these substances in syngas can be effectively influenced upon their formation by selecting an adequate gasifying reactor.

\subsection{Gasification unit description}

The unit consists of gas engine adapted for propulsion by the generator gas and synchronous electric current generator. The unit supplies a rated electrical output of $300 \mathrm{kWe}$ and a rated electrical output of about $510 \mathrm{kWt}$. The gasification generator is downdraft reactor which operates in vacuum mode. As a fuel, cut pieces of waste from the production process of sawmills are used. The combustion medium is air and temperature in the reactor ranged from $795-815^{\circ} \mathrm{C}$.

Main parts of the gasification unit:

1. Gasification generator

2. Cyclone separator

3. Series coolers

4. Gas washer

5. Second cooler

6. Centrifuge

7. Filter 


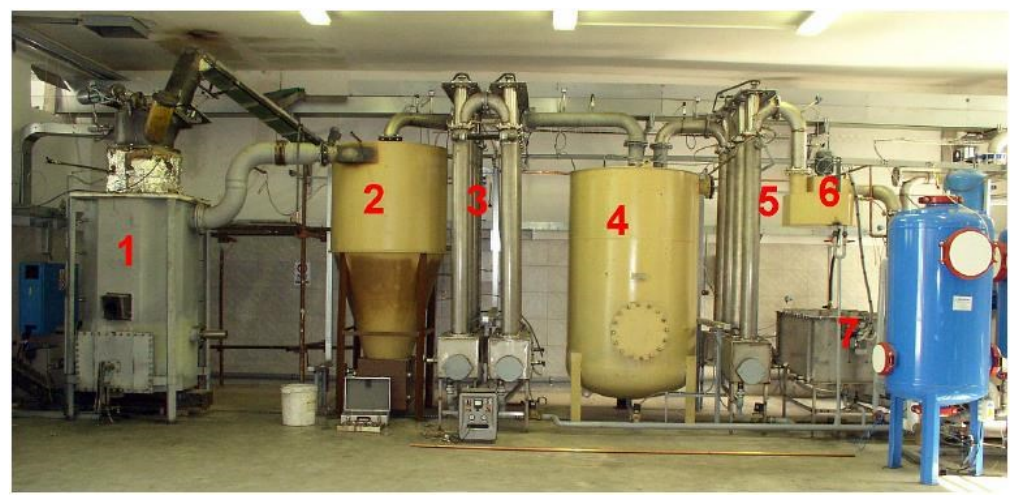

Fig. 1. Gasification unit.

\subsection{Fuel used in gasification process}

Fuel used in this study was waste from the production process of sawmills. The fuel is collected from several processes and stored in open containers for better drying. The resulting waste has a different size. Pieces of wood are from 2 to $10 \mathrm{~cm}$ thick, $5 \mathrm{~cm}$ wide and 5 to $20 \mathrm{~cm}$ in length (see in Figure 2). Such a particle size of fuel is appropriate for the reactor and allows it to contact the gasification agent throughout the reactor. Composition of the fuel was obtained using elemental analysis by the X-ray fluorescence spectroscopy (SPECTRO XEPOS new energy dispersive X-ray fluorescence spectrometer).

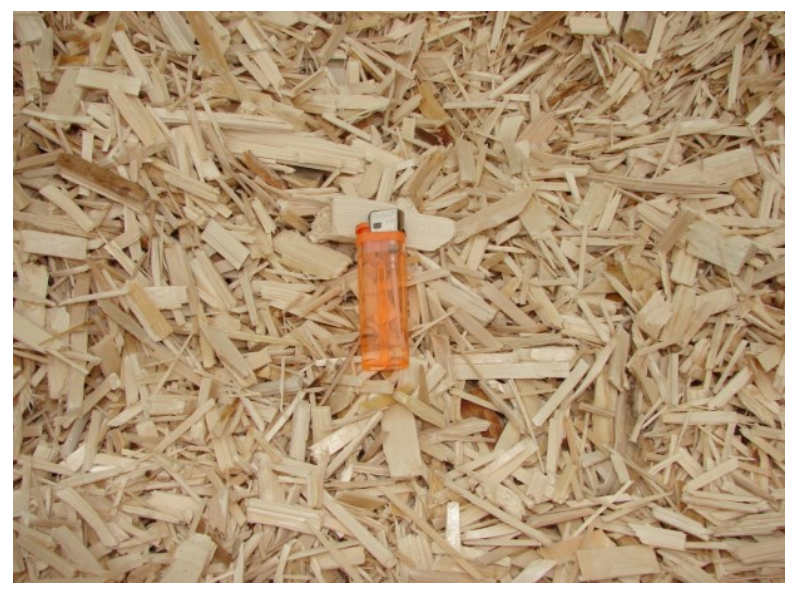

Fig. 2. Wood chips used as fuel.

\subsection{Methods used for syngas characterization}

A detailed analysis of the generated gas was performed by ON-Line and OFF-Line method. The ON-Line method included measurements of basic components $\left(\mathrm{O} 2, \mathrm{CO}, \mathrm{CH}_{4}, \mathrm{CO}_{2}\right)$ with GAS 3100P SYNGAS analyzer. The OFF-Line method included later detailed analysis of proced gas which was colected to the tedlar bags. The composition of colected gas was consequently determined in the laboratory by gas chromatography (Chrom 5) with MS 5A, Chromosorb 102, and Porapak QS columns with TCD and FID detectors. 


\section{Results and discussion}

\subsection{Characterization of the fuel used in gasification process}

The following Table 1. presents the physical and chemical composition of the fuel used in the installation. Moisture content (7\% mass) in the fuel is at a low level, within the limits of tolerance for a reactor. The high calorific value of $18.86 \mathrm{MJ}_{\mathrm{kg}} \mathrm{kg}^{-1}$ positively effects stability of the gasification process. Results of composition of fuel flammables are shown in Table 2 .

Table 1. Characterization of the fuel used in gasification process.

\begin{tabular}{|c|c|}
\hline Properties & value \\
\hline Fuel type & wood chips \\
\hline High heating value $\mathrm{HHV}$ & 18.86 MJ.kg-1 d.b. \\
\hline Moisture $\mathrm{W}_{\mathrm{r}}$ & $7.0 \%$ mass r.b. \\
\hline Ash $\mathrm{A}_{d}$ & $0.7 \%$ mass d.b. \\
\hline Volatile flammable matter $V_{d}$ & $77.2 \%$ mass d.b. \\
\hline Fixed carbon $\mathrm{FC}_{\mathrm{d}}$ & $22.1 \%$ mass d.b. \\
\hline Bulk density BD & 180 kg.m $\mathrm{m}^{-3} \quad$ d.b. \\
\hline
\end{tabular}

Table 2. Composition of fuel flammables.

\begin{tabular}{|c|c|}
\hline Component unit & value \\
\hline $\mathrm{C}$ & $47.87 \%$ mass \\
\hline $\mathrm{H}$ & $6.41 \%$ mass \\
\hline $\mathrm{O}$ & $45.62 \%$ mass \\
\hline $\mathrm{N}$ & $0.1 \%$ mass \\
\hline $\mathrm{S}$ & $0.01 \%$ mass \\
\hline
\end{tabular}

\subsection{Characterization of produced gas}

Table 3 presents the results of the analysis of syngas made by ON-Line measurements and also analysis of samples taken to the tedlar bags. In presented summary of the main components occurs oxygen which is the result of a leak in the system for gasification or sampling installation. Its content is so small and does not cause danger to the whole devices. More than 50 percentage nitrogen is caused by using air as an agent in the gasification process. This is the simplest form of fuel gasification in which we obtain a gas with low calorific value $5.2 \mathrm{MJ}_{\mathrm{m}} \mathrm{m}^{-3}$. Percentage part of flammable substances in gas is about $40 \%$ and depends on the temperature of the gasification process, equitable access medium, time of reaction, calorific value and fuel humidity. 
Table 3. The composition of syngas.

\begin{tabular}{|c|c|}
\hline Substances & Content \% vol. \\
\hline $\mathrm{O}_{2}$ in sample & 1.095 \\
\hline $\mathrm{CO}_{2}$ & 10.5175 \\
\hline $\mathrm{H}_{2}$ & 16.4225 \\
\hline $\mathrm{CO}$ & 20.5175 \\
\hline $\mathrm{CH}_{4}$ & 1.03 \\
\hline $\mathrm{N}_{2}$ & 50.71 \\
\hline $\mathrm{Ar}$ & 0.62 \\
\hline ethane & 0.00225 \\
\hline ethylene & 0.08925 \\
\hline acetylene & 0.07375 \\
\hline benzene & 0.01425 \\
\hline toluene & 0.001 \\
\hline $\mathrm{Q}_{\mathrm{s}}, \mathrm{MJ}^{-3}$ & 5.225 \\
\hline
\end{tabular}

\section{Conclusions}

The fixed bed gasification generator (down-draft), was able to steadily operates within various gasification conditions. The stability of syngas composition was very good. The low calorific value was $5.2 \mathrm{MJ} . \mathrm{m}^{-3}$ and percentage part of flammable substances in gas was about $40 \%$. In addition, purifying from the dust reached more than $99.3 \%$ efficiency. The increasing requirements of devices such as internal combustion engines, gas turbines and fuel cells requires lower dust limits in developing technologies with higher efficiency.

Experience gained in the operation of the presented technology of biomass gasification will help to create a fully commercial installation, permitting to supply the needs of heat and electricity from local sources.

This paper was conducted by project LO1404: Sustainable development of Centre ENET, within the framework of the project CZ.1.05/2.1.00/19.0389: Research Infrastructure Development of the CENET, by project of VŠB- Technical university of Ostrava, ENET Centre, Specific research SP2018/54- Measuring stand for testing of water-ring pumps, was supported by the Ministry of Education, Youth and Sports of the Czech Republic under OP RDE grant number CZ.02.1.01/0.0/0.0/16_019/0000753 "Research centre for low-carbon energy technologies", project Thermal processing of residues after dry fermentation TH02030120 and project Development of technology for purification and treatment of synthesis gases TH02020032 .

\section{References}

1. A. Demirbas, Prog. Energy Combust. Sci. 30, 219 (2004).

2. S. Honus, S. Kumagai, and T. Yoshioka, Energy Convers. Manag. 126, 1128 (2016).

3. S. Honus, S. Kumagai, O. Němček, and T. Yoshioka, Energy Convers. Manag. 126, 1118 (2016).

4. J. Kotowicz, A. Sobolewski, and T. Iluk, Energy 52, 265 (2013).

5. H. Raclavská, A. Corsaro, D. Juchelková, V. Sassmanová, and J. Frantík, Fuel Process. Technol. 131, 330 (2015).

6. J. Najser, V. Peer, and M. Vantuch, Biomass gasification for liquid fuel production, (2014), pp. 71-75.

7. I. Janajreh and M. Al Shrah, Energy Convers. Manag. 65, 783 (2013). 
8. J. Amaro, A. Z. Mendiburu, and I. Ávila, Energy 152, 371 (2018).

9. H. Knoef, Handbook biomass gasification, BTG Biomass Technology Group (2012).

10. N. Abdoulmoumine, S. Adhikari, A. Kulkarni, and S. Chattanathan, Appl. Energy 155, 294 (2015).

11. P. J. Woolcock and R. C. Brown, Biomass and Bioenergy 52, 54 (2013). 